\title{
IMPACT OF REPLACING INORGANIC COPPER AND ZINC IN CATFISH DIET WITH COPPER NANOPARTICLES AND ZINC NANOPARTICLES AT DIFFERENT LEVELS ON BODY PERFORMANCE AND BIOCHEMICAL PARAMETERS
}

\author{
MARWA FWAZ ${ }^{1}$; MOUSA, M.A ${ }^{2}$; ABD EL-GALIL, M.A ${ }^{3}$ and \\ HEGAZI, S.M ${ }^{4}$ \\ ${ }^{1}$ Demonstrator of Nutrition and Clinical Nutrition, Vet. Med., Sohag University. \\ 2 Associate Professor of Nutrition and Clinical Nutrition, Vet. Med., Sohag University. \\ 3 Professor of Fish Disease and Management, Vet. Med., Sohag University. \\ 4 Professor of Nutrition and Clinical Nutrition, Vet. Med., KFS University.
}

Received: 21 September 2020; Accepted: 20 October 2020

\begin{abstract}
The current study was carried out to investigate the effect of adding zinc and copper oxide nanoparticles metals at different levels from the recommended requirements of fish on the growth performance, biochemical parameters and some antioxidant enzymes in catfish. Three hundred and fifty channel catfish (Clarias gariepinius), average weight $(90 \pm 5 \mathrm{~g})$ were divided into seventh groups. The first group (control group) received the basal diet that contains normal requirements (copper sulfate 12.5 $\mathrm{mg} / \mathrm{kg}$ DM to provide $5 \mathrm{mg} / \mathrm{kg}$ DM copper, zinc oxide $25 \mathrm{mg} / \mathrm{kg}$ DM to provide $20 \mathrm{mg} / \mathrm{kg} \mathrm{DM}$ zinc); the second group ( $\mathrm{Gr} \mathrm{Cu} 1)$ received the basal diet with normal dose requirement from CuO-NPs $6.25 \mathrm{mg} / \mathrm{kg}$ DM to provide $5 \mathrm{mg} / \mathrm{kg}$ copper; the third group $(\mathrm{Gr} \mathrm{Cu} 2)$ received the basal diet with half requirement from copper (3.125 $\mathrm{mg} / \mathrm{kg} \mathrm{DM} \mathrm{CuO-NPs);} \mathrm{the} \mathrm{fourth} \mathrm{group} \mathrm{(} \mathrm{Gr} \mathrm{Cu} 3$ ) received the basal diet with quarter requirement from copper $(1.562 \mathrm{mg} / \mathrm{kg} \mathrm{DM} \mathrm{CuO}-\mathrm{NPs})$; the fifth group (Gr $\mathrm{Zn} \mathrm{1)} \mathrm{received} \mathrm{the} \mathrm{basal} \mathrm{diet} \mathrm{with} \mathrm{dose} \mathrm{requirement} \mathrm{from} \mathrm{zinc}(25 \mathrm{mg} / \mathrm{kg} \mathrm{DM}$ $\mathrm{ZnO}-\mathrm{NPs}$ ); the sixth group ( $\mathrm{Gr} \mathrm{Zn} 2$ ) received the basal diet with half requirement from zinc $(12.5 \mathrm{mg} / \mathrm{kg} \mathrm{DM} \mathrm{ZnO}-\mathrm{Nps})$; the seventh group ( $\mathrm{Gr} \mathrm{Zn} 3$ ) received the basal diet with quarter requirement from zinc (6.25 $\mathrm{mg} / \mathrm{kg}$ DM ZnO-NPs). Better responses were reported to feeding nanoparticles at quarter dose than normal dose for both elements $(\mathrm{ZnO}-\mathrm{CuO})$. These results were supported by biochemical and the antioxidant enzyme results. We could conclude that the uses of quarter requirements from $\mathrm{Zn}$ and $\mathrm{Cu}$ nanoparticles were recommended in our work for better performance and growth.
\end{abstract}

Keywords: Clarias gariepinus, Zinc oxide nanoparticles, Copper oxide nanoparticles, Growth performance, Biochemical Parameters, Antioxidant

Corresponding author: MARWA FWAZ

E-mail address: marwaahmedfwaz@gmail.com

Present address: Demonstrator of Nutrition and Clinical Nutrition, Vet. Med., Sohag University. 


\section{INTRODUCTION}

The life standards of human societies have been rigorously changed after introduction of modern technologies. One aspect of these new technologies is daily increase of emerging nanoproducts (Handy, 2012). Nanotechnology involves the synthesis of nanoscale particles that exhibit unique physiochemical properties like higher intestinal absorption, bioavailability and enhanced bactericidal and catalytic activities (Dube et al., 2010). Aquaculture is more than a science in its infancy; it is now recognized as a viable and profitable enterprise worldwide. As aquaculture technology has evolved, the push toward higher yields and faster growth has involved the enhancement or replacement of natural foods with prepared diets (NRC 1993). Minerals are essential nutrients for normal body processes; mineral requirements vary depending on forms, interactions with other elements, water quality and fish itself (age, size and species) (Tawfik et al., 2017). Copper is an essential trace element for vertebrates, including fish, for a large number of biological processes, mainly as a cofactor for some enzymes, such as cytochrome oxidase, superoxide dismutase, lysyl oxidase, dopamine hydroxylase and tyrosinase (Tan et al., 2011). Zinc is one of the most important trace minerals needed for good health of animals (Onuegbu et al., 2018). Zinc has both catalytic and structural roles in enzymes, and its antioxidant properties have been widely recognized (Maret, 2000), the objective of this study the effect of adding zinc and copper oxide nanoparticles metals at different levels on the recommended requirements of fish on the growth performance, biochemical parameters and some antioxidant enzymes in cat fish.

\section{MATERIALS AND METHODS}

\section{Experimental Fish}

A total number of three hundred and fifty (350) unsexed catfish (Clarias gariepinius (mean weight $90 \pm 5 \mathrm{~g}$ ) were obtained from a local commercial fish farm, Rasheed, Behara governorate, and were randomly distributed into seven circular tanks of 220 L capacity (50 fish per each tank) with similar initial weight. Fishes were fed daily (twice per day) with a feeding rate of (3\% of their body weight, $135 \mathrm{~g}$ for each group) with commercial pelleted feed according to (NRC 1993).

\section{Feeding:}

The experimental diets were formulated from commercially available ingredients. The basal ingredients of diets were soybean meal, corn, sunflower meal, fish meal. Diets were formulated to contain $32 \%$ crude protein as minimum, $2800 \mathrm{Kcal} / \mathrm{Kg}$ diet.

\section{Zinc and copper nanoparticles}

The formulated fish diets were enriched with nanoparticles of zinc oxide and copper oxide. Copper oxide nanoparticles (nano powder $<50 \mathrm{~nm}$ particle size (TEM) and zinc oxide nanoparticles (nano powder $<100 \mathrm{~nm}$ particle size (TEM) from Sigma Aldrich company. 
Table 1: Chemical composition and digestible energy value (Kcal/kg Diet) of the ingredients used in the experimental diets (as fed basis) (NRC 1993).

\begin{tabular}{ccccccc}
\hline \multirow{2}{*}{ Ingredients } & DE $($ Kcal/kg) & \multicolumn{5}{c}{ Chemical composition, \% } \\
\cline { 3 - 7 } & & DM & CP & EE & CF & Ash \\
\hline Soybean meal & 3.010 & 90 & 42 & 1.1 & 7.3 & 6.3 \\
\hline White Corn & 2.200 & 88 & 8 & 3.6 & 2.3 & 1.3 \\
\hline Sunflower meal & 2.870 & 93 & 33.96 & 2.9 & 11.7 & 7.5 \\
\hline Fish meal & 4.060 & 92 & 61.42 & 9.6 & 0.7 & 19 \\
\hline
\end{tabular}

*values of digestible energy (DE) were calculated according to NRC (1993)

Table 2: Chemical composition (\%) of the experimental diet:

\begin{tabular}{cccccccc}
\hline Item & Control & Gr Cu 1 & Gr Cu 2 & Gr Cu 3 & Gr Zn 1 & Gr Zn 2 & Gr Zn 3 \\
\hline Soybean meal & 40 & 40 & 40 & 40 & 40 & 40 & 40 \\
\hline White Corn & 28 & 28 & 28 & 28 & 28 & 28 & 28 \\
\hline Sunflower meal & 20 & 20 & 20 & 20 & 20 & 20 & 20 \\
\hline Fish meal & 10 & 10 & 10 & 10 & 10 & 10 & 10 \\
\hline Slack & 1.125 & 1.125 & 1.125 & 1.125 & 1.125 & 1.125 & 1.125 \\
\hline $\begin{array}{c}\text { 1- Calcium } \\
\text { carbonate }\end{array}$ & 0.7 & 0.7 & 0.7 & 0.7 & 0.7 & 0.7 & 0.7 \\
\hline $\begin{array}{c}\text { 2- Sodium } \\
\text { chloride }\end{array}$ & 0.3 & 0.3 & 0.3 & 0.3 & 0.3 & 0.3 & 0.3 \\
\hline $\begin{array}{c}\text { 3- Vitamin C } \\
\text { - } 0.025\end{array}$ & 0.025 & 0.025 & 0.025 & 0.025 & 0.025 & 0.025 \\
\hline
\end{tabular}

The rest of slack was completed from white corn

Premix manually prepared to provide the following per $\mathrm{kg}$ of diet: vitamin A, 1000$2000 \mathrm{IU}$; vitamin E, $50 \mathrm{IU}$; vitamin D, $500 \mathrm{IU}$; thiamine, $1 \mathrm{mg}$; riboflavin, $9 \mathrm{mg}$; niacin, $14 \mathrm{mg}$; B6, $3 \mathrm{mg}$; folate, $1.5 \mathrm{mg}$; choline, $400 \mathrm{mg}$; vitamin C, 25-50 mg; pantothenic, $15 \mathrm{mg}$; magnesium, $0.04 \%$; phosphorus, $0.45 \%$; copper, $5 \mathrm{mg}$ (inorganic or nanoparticles); iodine, 1.1E mg; iron, $30 \mathrm{mg}$; manganese, $2.4 \mathrm{mg}$; zinc, $20 \mathrm{mg}$ (inorganic or nanoparticles); selenium, $0.25 \mathrm{mg}$. 


\section{Methods}

\section{Experimental groups:}

The experiment was designed into seven groups each group contain 50 fish; The first group (control group) received the basal diet that contains normal requirements (copper sulfate $12.5 \mathrm{mg} / \mathrm{kg}$ DM to provide $5 \mathrm{mg} / \mathrm{kg}$ copper (copper sulfate contains $39.81 \%$ copper)), zinc oxide $25 \mathrm{mg} /$ $\mathrm{kg}$ DM to provide $20 \mathrm{mg} / \mathrm{kg}$ zinc (zinc oxide contains $80 \%$ zinc)); the second group $(\mathrm{Gr} \mathrm{Cu} 1)$ received the basal diet with normal dose requirement from copper $(6.25 \mathrm{mg} / \mathrm{kg} \mathrm{DM} \mathrm{CuO}-$ NPs to provide $5 \mathrm{mg} / \mathrm{kg}$ copper (copper oxide contains $79.88 \%$ copper); the third group ( $\mathrm{Gr} \mathrm{Cu} 2$ ) received the basal diet with half requirement from copper $3.125 \mathrm{mg}$ $/ \mathrm{kg} \mathrm{DM} \mathrm{CuO-NPs);} \mathrm{the} \mathrm{fourth} \mathrm{group}$ $(\mathrm{Gr} \mathrm{Cu} 3)$ received the basal diet with quarter requirement from copper (1.56 $\mathrm{mg} / \mathrm{kg}$ DM CuO-NPs); the fifth group ( $\mathrm{Gr} \mathrm{Zn} \mathrm{1)}$ received the basal diet with dose requirement from zinc $(25 \mathrm{mg}$ $/ \mathrm{kg}$ DM ZnO-NPs); the sixth group (Gr $\mathrm{Zn} \mathrm{2)} \mathrm{received} \mathrm{the} \mathrm{basal} \mathrm{diet} \mathrm{with}$ half requirement from zinc $(10 \mathrm{mg} / \mathrm{kg}$ DM ZnO-NPs); the seventh group ( $\mathrm{Gr}$ $\mathrm{Zn} 3)$ received the basal diet with quarter requirement from zinc $(5 \mathrm{mg}$ $/ \mathrm{kg} \mathrm{DM}$ ZnO-NPs).This experiment was carried out according to the regulation of nutrition and clinical nutrition department at fish research lab, faculty of veterinary medicine, Sohag university, Sohag governorate and lasted 60 days from 2 November 2019 to 31 December 2019.

\section{Measurements:}

The experiment was lasted 60 days (four periods 15 days each). In each period, we collected fish and serum samples for body performance tests ((body weight gain- feed conversion ratio) and for estimation some biochemical parameters (cholesteroltriglycerides -alanine aminotransferase-aspartate aminotransferase-alkaline phosphatase enzyme- -lactate dehydrogenase enzyme - creatinine- urea). Finally, at the end of the experiment after 60 days we estimated some serum Antioxidants (catalase-glutathione peroxidase-superoxide dismutase).

\section{Feed Preparation}

All feed ingredients were purchased from local market. All feed ingredients were grinded to form a feed pellets which let to dry at room temperature.

\section{Proximate nutrient composition of experimental rations}

The experimental feed was analyzed using the standard analysis method of the Association of Official Analytical Chemist (AOAC, 2001). They were analyzed as follows: The moisture content of the sample was determined using air oven at $105^{\circ} \mathrm{C}$, crude protein was obtained by using Micro-Kjeldahl method (Behrotest inkjel). The ash content was determined using muffle furnace (Nabertherm) at $600^{\circ} \mathrm{C}$ for two hours until constant weight of ash 
was obtained. Crude fiber was determined by fiber analyzer (Ankom 2000) after the residue was ashed and loss in weight was recorded as crude fiber.

\section{Growth Performance:}

Growth performance parameters were carried out at a regular interval every 15 days for 60 days to measure Body weight gain (BWG), Feed conversion ratio $(\mathrm{FCR})$.

\section{Biochemical Parameters Analysis:}

Frozen serum samples were analyzed for determination of the activities of aspartic aminotransferase (AST) and alanine aminotransferase (ALT) (Tietz et al., 1994) as well as cholesterol (Allain et al., 1974), triglyceride (Shephard et al., 1986), lactate dehydrogenase (LDH), alkaline phosphatase (ALP) (Marsh et al.,
1959), urea and creatinine (Tietz et al., 1986) by using commercial kits (Chema Diagnostica and Spectrum) and determination of some antioxidants as catalase, glutathione peroxidase and superoxide dismutase (Aebi 1984) using commercial kits (Bio -Diagnostic) using spectrophotometer.

\section{Statistical analysis}

Experimental data subjected to several statistical analyses from which means \pm standard errors was calculated using the Graph-Pad Prism (GraphPad Software, San Diego, CA, USA). Differences were testing for significance by one - way analysis of variance. Differences $(\mathrm{P}<0.05)$ among treatment were tested using Tukey's Honest significant difference test.

\section{RESULTS}

Table 3: Effect of adding some nanominerals (copper and zinc) on body weight gain (g) of catfish (Clarias gariepinus).

\begin{tabular}{cccccc}
\hline \multirow{2}{*}{ GN } & \multicolumn{5}{c}{ Experimental Time } \\
\cline { 2 - 6 } & $\begin{array}{c}\text { From 1 - 15 } \\
\text { Days }\end{array}$ & $\begin{array}{c}\text { From 16-30 } \\
\text { Days }\end{array}$ & $\begin{array}{c}\text { From 31- 45 } \\
\text { Days }\end{array}$ & $\begin{array}{c}\text { From 46- 60 } \\
\text { Days }\end{array}$ & Cumulatives \\
\hline Control & $29.2 \pm 2.02^{\mathrm{b}}$ & $34.2 \pm 1.2$ & $31.35 \pm 1.5$ & $34.66 \pm 1.1^{\mathrm{d}}$ & $129.41 \pm 3.64$ \\
\hline $\mathrm{Gr} \mathrm{Cu} \mathrm{1}$ & $30.9 \pm 1.1^{\mathrm{b}}$ & $38.17 \pm 1.4^{\mathrm{c}}$ & $31.63 \pm 11$ & $28.17 \pm 1.2$ & $128.87 \pm 3.83$ \\
\hline $\mathrm{Gr} \mathrm{Cu} \mathrm{2}$ & $33.38 \pm 1.1^{\mathrm{a}}$ & $35.21 \pm 1.4$ & $36.98 \pm 1.6^{\mathrm{d}}$ & $35.27 \pm 1.8^{\mathrm{d}}$ & $140.84 \pm 4.45^{\mathrm{c}}$ \\
\hline $\mathrm{Gr} \mathrm{Cu} \mathrm{3}$ & $34.71 \pm 1.2^{\mathrm{a}}$ & $42.96 \pm 1.8^{\mathrm{b}}$ & $42.72 \pm 1.9^{\mathrm{b}}$ & $41.78 \pm 2.1^{\mathrm{b}}$ & $162.17 \pm 4.65^{\mathrm{b}}$ \\
\hline $\mathrm{Gr} \mathrm{Zn} \mathrm{1}$ & $28.45 \pm 0.4^{\mathrm{b}}$ & $32.33 \pm 1.9$ & $30.41 \pm 2.1$ & $34.66 \pm 2.21^{\mathrm{d}}$ & $125.85 \pm 3.5$ \\
\hline $\mathrm{Gr} \mathrm{Zn} \mathrm{2}$ & $29.61 \pm 1.5^{\mathrm{b}}$ & $35.78 \pm 1.2$ & $39.08 \pm 2.4^{\mathrm{c}}$ & $37.14 \pm 2.4^{\mathrm{c}}$ & $141.61 \pm 4.12^{\mathrm{c}}$ \\
\hline $\mathrm{Gr} \mathrm{Zn} \mathrm{3}$ & $33.33 \pm 0.8^{\mathrm{a}}$ & $45.5 \pm 1.6^{\mathrm{a}}$ & $45.24 \pm 1.7^{\mathrm{a}}$ & $44.21 \pm 1.5^{\mathrm{a}}$ & $168.28 \pm 3.23^{\mathrm{a}}$ \\
\hline
\end{tabular}

Means in the same column with different superscripts are significantly different $(\mathrm{P} \leq 0.05)$ 
Table 4: Effect of adding some nanominerals (copper and zinc) on feed conversion ratio of catfish (Clarias gariepinus).

\begin{tabular}{cccccc}
\hline & \multicolumn{5}{c}{ Experimental Time } \\
\cline { 2 - 6 } GN & $\begin{array}{c}\text { From 1 - } \\
\text { 15 Days }\end{array}$ & $\begin{array}{c}\text { From 16-30 } \\
\text { Days }\end{array}$ & $\begin{array}{c}\text { From 31- 45 } \\
\text { Days }\end{array}$ & $\begin{array}{c}\text { From 46- 60 } \\
\text { Days }\end{array}$ & Cumulatives \\
\hline Control & 1.40 & 1.58 & 2.21 & 2.41 & 1.92 \\
\hline Gr Cu 1 & 1.32 & 1.43 & 2.27 & 3.06 & 1.97 \\
\hline Gr Cu 2 & 1.22 & 1.59 & 1.94 & 2.51 & 1.83 \\
\hline Gr Cu 3 & 1.18 & 1.32 & 1.77 & 2.27 & 1.66 \\
\hline Gr Zn 1 & 1.4 & 1.66 & 2.24 & 2.36 & 1.94 \\
\hline Gr Zn 2 & 1.38 & 1.52 & 1.79 & 2.36 & 1.79 \\
\hline Gr Zn 3 & 1.22 & 1.23 & 1.69 & 2.19 & 1.61 \\
\hline
\end{tabular}

Table 5: Effect of adding some nanominerals (copper and zinc) on Serum biochemical parameters of catfish (Clarias gariepinus):

\begin{tabular}{|c|c|c|c|c|c|c|c|c|}
\hline GN & $\begin{array}{c}\text { Triglyceride } \\
\text { (mg/dl) }\end{array}$ & $\begin{array}{c}\text { Cholesterol } \\
\text { (mg/dl) }\end{array}$ & $\begin{array}{c}\text { Urea } \\
(\mathrm{mg} / \mathrm{dl})\end{array}$ & $\begin{array}{c}\text { Creatinine } \\
\text { (mg/dl) }\end{array}$ & $\begin{array}{c}\text { ALT } \\
(\mathbf{I U} / \mathbf{L})\end{array}$ & $\begin{array}{c}\text { AST } \\
(\text { IU/L) }\end{array}$ & $\begin{array}{l}\mathbf{A L P} \\
(\mathbf{U} / \mathbf{L})\end{array}$ & $\begin{array}{l}\text { LDH } \\
(\mathbf{U} / \mathbf{L})\end{array}$ \\
\hline Control & $162 \pm 11.91$ & $\begin{array}{c}149.67 \pm \\
8.94^{\mathrm{a}}\end{array}$ & $\begin{array}{c}7.67 \pm \\
1.36^{\mathrm{a}}\end{array}$ & $\begin{array}{c}0.37 \pm \\
0.03^{b}\end{array}$ & $\begin{array}{l}8.92 \pm \\
0.13^{b}\end{array}$ & $\begin{array}{l}129 \pm \\
7.95^{\mathrm{bc}}\end{array}$ & $\begin{array}{c}45.67 \\
\pm 2.34^{\mathrm{b}}\end{array}$ & $\begin{array}{l}512.3 \pm \\
23.06^{\mathrm{c}}\end{array}$ \\
\hline Gr Cu 1 & $\begin{array}{c}164.333 \pm \\
11.91\end{array}$ & $\begin{array}{c}168.67 \pm \\
11.11^{\mathrm{a}}\end{array}$ & $\begin{array}{c}7.67 \pm \\
1.43^{\mathrm{a}}\end{array}$ & $\begin{array}{l}0.37 \pm \\
0.03^{\mathrm{b}}\end{array}$ & $\begin{array}{c}11.5 \pm \\
0.21^{\mathrm{a}}\end{array}$ & $\begin{array}{l}140.33 \\
\pm 3.07^{\mathrm{a}}\end{array}$ & $\begin{array}{c}64.34 \\
\pm 4.16^{\mathrm{a}}\end{array}$ & $\begin{array}{c}360.24 \pm \\
30.29\end{array}$ \\
\hline Gr Cu 2 & $\begin{array}{c}139.67 \pm \\
11.14\end{array}$ & $\begin{array}{c}153.00 \pm \\
5.41^{\mathrm{a}}\end{array}$ & $\begin{array}{l}6.33 \pm \\
0.92^{\mathrm{ab}}\end{array}$ & $\begin{array}{c}0.52 \pm \\
0.05^{\mathrm{a}}\end{array}$ & $\begin{array}{l}8.34 \pm \\
0.31^{\mathrm{b}}\end{array}$ & $\begin{array}{l}135.67 \\
\pm 3.18^{\mathrm{b}}\end{array}$ & $\begin{array}{c}65.36 \\
\pm 3.27^{\mathrm{a}}\end{array}$ & $\begin{array}{c}612.33 \pm \\
23.83^{\mathrm{a}}\end{array}$ \\
\hline Gr Cu 3 & $138 \pm 7.89$ & $\begin{array}{c}143.67 \pm \\
7.47^{\mathrm{b}}\end{array}$ & $\begin{array}{c}5.67 \pm \\
0.67^{\mathrm{b}}\end{array}$ & $\begin{array}{l}0.36 \pm \\
0.03^{\mathrm{b}}\end{array}$ & $\begin{array}{l}8.6 \pm \\
0.25\end{array}$ & $\begin{array}{c}127.67 \\
\pm 9.91^{\mathrm{bc}}\end{array}$ & $\begin{array}{c}56.22 \\
\pm 3.22^{\mathrm{b}}\end{array}$ & $\begin{array}{c}623.80 \pm \\
21.71^{\mathrm{a}}\end{array}$ \\
\hline Gr Zn 1 & $\begin{array}{c}141.67 \pm \\
5.23\end{array}$ & $\begin{array}{c}147.00 \pm \\
6.79^{\mathrm{a}}\end{array}$ & $\begin{array}{l}6.33 \pm \\
0.82^{\mathrm{ab}}\end{array}$ & $\begin{array}{l}0.33 \pm \\
0.03^{\mathrm{b}}\end{array}$ & $\begin{array}{l}11.4 \pm \\
0.29^{\mathrm{a}}\end{array}$ & $\begin{array}{l}132.00 \\
\pm 9.37^{\mathrm{b}}\end{array}$ & $\begin{array}{c}58.7 \pm \\
3.18^{\mathrm{b}}\end{array}$ & $\begin{array}{c}632.33 \pm \\
21.61^{\mathrm{a}}\end{array}$ \\
\hline Gr Zn 2 & $\begin{array}{c}117.67 \pm \\
0.82\end{array}$ & $\begin{array}{c}138.00 \pm \\
7.74^{\mathrm{b}}\end{array}$ & $\begin{array}{c}6.67 \pm \\
1.67^{\mathrm{ab}}\end{array}$ & $\begin{array}{c}0.31 \pm \\
0.15^{\mathrm{b}}\end{array}$ & $\begin{array}{l}8.31 \pm \\
0.11^{\mathrm{b}}\end{array}$ & $\begin{array}{l}127.33 \\
\pm 5.12\end{array}$ & $\begin{array}{l}30 \pm \\
5.25^{\mathrm{c}}\end{array}$ & $\begin{array}{c}353.47 \pm \\
29.93\end{array}$ \\
\hline Gr Zn 3 & $\begin{array}{c}102.33 \pm \\
12.42\end{array}$ & $\begin{array}{c}116.00 \pm \\
5.48^{\mathrm{c}}\end{array}$ & $\begin{array}{c}5.07 \pm \\
0.17^{\mathrm{b}}\end{array}$ & $\begin{array}{c}0.31 \pm \\
0.02^{\mathrm{b}}\end{array}$ & $\begin{array}{l}8.03 \pm \\
0.22^{\mathrm{b}}\end{array}$ & $\begin{array}{r}123.00 \\
\pm 7.79^{\mathrm{c}}\end{array}$ & $\begin{array}{c}29 \pm 2 . \\
55^{\mathrm{c}}\end{array}$ & $\begin{array}{l}584.66 \\
\pm 23.73^{\mathrm{b}}\end{array}$ \\
\hline
\end{tabular}

Means in the same column with different superscripts are significantly different $(\mathrm{P} \leq 0.05)$ 
Table 6: Effects of adding some nanominerals (copper and zinc) on antioxidant (U/L) of catfish (clarias Gariepinus).

\begin{tabular}{|c|c|c|c|c|c|c|c|}
\hline GN & Control & Gr Cu 1 & $\mathrm{Gr} \mathrm{Cu} 2$ & $\mathrm{Gr} \mathrm{Cu} 3$ & Gr Zn 1 & Gr Zn 2 & Gr Zn 3 \\
\hline Catalase & $\begin{array}{c}315.67 \pm \\
1.94^{\mathrm{c}}\end{array}$ & $\begin{array}{c}162.33 \pm \\
5.23^{\mathrm{d}}\end{array}$ & $\begin{array}{c}306.33 \pm \\
2.44^{\mathrm{c}}\end{array}$ & $\begin{array}{c}322.33 \pm \\
3.25^{\mathrm{b}}\end{array}$ & $\begin{array}{c}324.83 \pm \\
6.64^{\mathrm{b}}\end{array}$ & $\begin{array}{c}337.67 \pm \\
6.97^{\mathrm{b}}\end{array}$ & $\begin{array}{c}353.67 \pm \\
9.63^{\mathrm{a}}\end{array}$ \\
\hline SOD & $\begin{array}{l}74.6667 \\
\pm 1.63^{\mathrm{e}}\end{array}$ & $\begin{array}{c}84.1667 \\
\pm 2.69^{\mathrm{e}}\end{array}$ & $\begin{array}{c}204.33 \pm \\
2.57^{\mathrm{d}}\end{array}$ & $\begin{array}{c}208.00 \pm \\
3.56^{\mathrm{d}}\end{array}$ & $\begin{array}{c}230.67 \pm \\
3.44^{\mathrm{c}}\end{array}$ & $\begin{array}{c}254.67 \pm \\
2.06^{\mathrm{b}}\end{array}$ & $\begin{array}{c}277.67 \pm \\
1.22^{\mathrm{a}}\end{array}$ \\
\hline Glutathione & $\begin{array}{c}422.67 \pm \\
9.23^{\mathrm{d}}\end{array}$ & $\begin{array}{c}154.33 \pm \\
4.89^{\mathrm{f}}\end{array}$ & $\begin{array}{c}379.33 \pm \\
9.62^{\mathrm{e}}\end{array}$ & $\begin{array}{c}510.67 \pm \\
6.22^{\mathrm{c}}\end{array}$ & $\begin{array}{c}320.33 \pm \\
9.21^{\mathrm{e}}\end{array}$ & $\begin{array}{c}525.00 \pm \\
9.01^{\mathrm{b}}\end{array}$ & $\begin{array}{l}542 \pm \\
6.35^{\mathrm{a}}\end{array}$ \\
\hline
\end{tabular}

Means in the same column with different superscripts are significantly different $(\mathrm{P} \leq 0.05)$

\section{DISCUSSION}

Nutritionally balanced diets are necessary for culture system; therefore, micronutrients must be supplied at adequate levels in the prepared diets to support optimal growth and production efficiency (Swain et al., 2016). The normal growth performance of cultured fish species requires a balanced diet containing all the necessary nutrients, including copper $(\mathrm{Cu})$ (Mohseni et al., 2014; El Basuini et al., 2016).

In our work, growth performance and feed utilization parameters (tables 3, 4) were affected significantly by both CuO-NPs and ZnO-NPs supplementations, which is in agreement with the previous studies demonstrated that the implementation of $\mathrm{Cu}$ and vitamin $\mathrm{C}$ supplementations to enhance growth rates, feed utilization and immunity response of several fish species (Mohseni et al., 2014). Also, Swain et al. (2016), confirm the improvement in growth in fishes with using nanoparticle minerals.

In agreement with our results, El Basuini et al. (2016) reported that enhanced growth performance and feed utilization were generally observed in fish fed diets supplemented with $\mathrm{Cu}$ NPs compared to fish fed basal diets. Onuegbu et al. (2018), observed that there was sustained increased in fish weight across all supplementation levels of both $\mathrm{Cu}-\mathrm{NPs}$ and $\mathrm{CuO}$ during the culture period.

The positive effects of using the $\mathrm{Cu}$ NPs could be attributed to its small particle size, would possibly pass the gastrointestinal barriers, get into the blood stream more easily and impact more effectively on the blood compared to macro $\mathrm{CuO}$. It may also implied that supplementation $\mathrm{Cu}-\mathrm{NPs}$ is safe and unharmful to fish fingerlings (Onuegbu et al., 2018). 
However, no significant differences have been reported as a result of $\mathrm{Cu}$ supplementation on weight gain and feed efficiency in case of channel catfish (Gatlin \& Wilson., 1986).

In contrast, Chen et al. (2013), reported that the growth suppression in the high dose of Cuo-NPs could be the cause of the reduction in growth performance which was most likely due to two reasons: first, $\mathrm{Cu}$ exposure caused increased metabolic expenditure for detoxification and maintenance of homeostasis; second, higher $\mathrm{Cu}$ exposure reduced feed intake, which would in turn lead to reduced growth.

Also, growth suppression could attributed to, loss of appetite in rainbow trout (Lanno et al., 1985) Nile tilapia, Oreochromis niloticus (Shaw \& Handy 2006) and juvenile yellow catfish (Tan et al., 2011), when exposed to excessive dietary copper (Mohseni et al., 2014).

The growth performance resulted by using Zn-NPs as feed supplements, confirmed an improvement with using half and quarter of the recommended dose of Zn, by (NRC, 1993) of fish.

Obtained results of using Zn-NPs are supported by findings of Khan et al. (2016), who was reported that zinc nanoparticles enhance the growth rate in fishes.

Similarly, the improvement in growth rate and FCR as reported in this experiment has also been recorded by Ahmed et al. (2012) who also indicate the scope of nanotechnology for the enhancement of healthy fish production.

The fish fed Zno-NPs form showed a higher growth rate followed by $\mathrm{CuO}$ NPs nanoparticle group at quarter and half dose then the control group, while less growth was observed in groups offered dietary $\mathrm{ZnO}$ nanoparticle supplementation at normal dose.

In agreements with our results, Faiz et al. (2015) observed a significantly higher gain, growth rate and improved FCR of fish fed ZnO-NP supplemented diet compared to $\mathrm{ZnO}$ enriched diet at the same level may be due to small size (50-60 nm) of nanoform of $\mathrm{ZnO}$.

The better performance of fish could be attributed to a higher intestinal absorption, bioavailability and catalytic activities (Alishahi et al., 2011). Also the positive effect of $\mathrm{Zn}$ nanoparticles on growth performance may be attributed to somatic growth by stimulation of DNA and RNA synthesis and cell division (Siklar et al., 2003).

Tawfik et al. (2017) reported that fish fed diet supplemented with $\mathrm{Zn}$ in nanoform showed significantly $(\mathrm{p}<0.05)$ high \%WG, besides their observation that ZnO-NPs supplementation enhanced the growth rates more than conventional $\mathrm{ZnO}$, which were sometimes double the weight gain. While, Rather et al. (2011) reported that reduction of macromolecule to nanoscale changed their properties and increased their application. 
Blood biochemistry parameters are one of the important indicators for fish general health condition as well as the physiological stress response (Dawood et al., 2015). Metabolic enzymes such as aspartate aminotranseferase enzyme (AST) and alanine aminotranseferase enzyme (ALT) are often used for the evaluation of liver function as they are released into the blood during injury or damage to the liver cells (Dawood et al., 2016). Moreover, Kim \& Kang (2004) showed that $\mathrm{Cu}$ exposure increased ALT and AST serum concentrations with increasing time and dose in juvenile rock fish.

These results are in agreements with the findings of Abdel-Khalek et al. (2015) showed that ALP, AST and ALT concentrations in Oreochromis niloticus increased after 96 hours of exposure to $\mathrm{CuO}-\mathrm{NPs}$ at higher levels.

While Bakalli et al. (1995) claim that copper addition contributes to a decreased level of triglycerides and reduced cholesterol synthesis in blood plasma and tissues of animals.

The increased activity of AST and ALT in tissues of $\mathrm{ZnO}-\mathrm{NPs}$ treated fish may indicate the increased rate of proteins metabolism in cells (Taheri et al., 2017).

ALP plays a significant role in phosphate hydrolysis and in membrane transport and it also acts as a good biomarker of stress in biological systems (Murray et al., 2003). Moreover, the administration of $\mathrm{ZnO}$ NPs caused a significant decrease in ALP activity in liver of fish (Taheri et al., 2017).
An increase in zinc level in liver can account for a reduced ALP activity because high levels of zinc can have deterrent effects on ALP activity (Farah et al., 2012). Increased ALP activity in kidney may be due to the effects of $\mathrm{ZnO}$ NPs on transphosphorylation activity as well as a metabolic dysfunction in cells (Taheri et al., 2017).

Lactate dehydrogenase (LDH) is an oxidoreductase enzyme that catalyses the inter conversion of pyruvate and lactate (Swain et al., 2019). Cells release LDH into the bloodstream after tissue damage or red blood cell haemolysis. Since LDH is a fairly stable enzyme, it has been widely used to evaluate the presence of damage and toxicity of tissues and cells (Taheri et al., 2017).

In contrary to our result, the significantly increased creatinine level in the nano group suggested that the renal dysfunction be most likely caused by nano zinc administration (Najafzadeh et al., 2013). Moreover, it was found that administration of high levels $\mathrm{ZnO}$ NPs was accompanied with signs of toxicity, including an increased level of LDH enzyme activity (Mohamad, 2013).

Oxidative stress is a state of abundance of reactive oxygen species (ROS), which interferes with biological processes by disturbing or damaging homeostasis. The activity of oxidative stress enzyme GSH, and GST indicates the alteration of normal homeostasis.

Also, in agreement with our results, administering low concentrations of 
ZnO-NPs may enhance total antioxidant capacity of the cell by increasing the activity level of enzymatic (SOD and CAT) and nonenzymatic (protein antioxidants and glutathione) antioxidant system, reducing the ROS level and inhibiting the activity of nitric-oxide synthase and NADPH oxidase (Prasad, 2014). Furthermore, $\mathrm{Zn}$ inhibits the influence of lipid peroxidation products on the cellular antioxidant system (Prasad, 2014). Moreover, serum SOD activity was found to have risen in nanoparticles-treated groups due to adaptation of the fish to the nanoparticles (Sedeño-Díaz and LópezLópez., 2012).

Previous study reported that SOD and CAT activity and gene expression fluctuated with the concentrations of ZnNPs, SOD activity and gene expression were increased at lower ZnNPs concentrations and reduced at the highest concentrations (Saddick et al., 2017). The same result was reported by Xiong et al. (2011) who proved the inhibitory effect of ZnONPs on liver SOD in fish exposed to $5 \mathrm{mg} / \mathrm{L}$ ZnONPs.

\section{CONCLUSION}

From the present study we concluded that using of $\mathrm{Cu}$ and $\mathrm{Zn}$ nanoparticles in the aquaculture diets could be used as minimal as quarter dose for both inorganic copper and zinc; The beneficial effects for both nanoparticles elements copper and zinc on biochemical and antioxidant parameters do not decrease by decreasing amount but it become better. We need further works to investigate its action on digestibility, digestive enzymes and histopathology on liver, kidney and intestine.

\section{ACKNOWLEDGMENTS}

The authors gratefully acknowledge the support offered by President of Sohag University professor Dr Ahmed Aziz and his kind contributions throughout the research. We gratefully thank Dr. Ahmed El-Sayed Osman for his valuable assistance during our work.

\section{REFERENCES}

Abdel-Khalek, A.; Kadry, M.A.M.; Badran, S.R. and Marie, M.A.S. (2015): Comparative toxicity of copper oxide bulk and nanoparticles in Nile Tilapia; Aebi H. (1984): Catalase in vitro. Methods in Enzymology. 105: 121-126.

Ahmed, M.S.; Shafiq, K. and Kiani, M.S. (2012): Growth performance of major carp, Labeo rohita fingerlings on commercial feeds. Journal of Animal and Plant Sciences, 6(2): 421-431.

Alishahi, A.; Mirvaghefi, A.; Tehrani, M.R.; $\quad$ Farahmand, H.; Shojaosadati, S.A.; Dorkoosh, F.A. and Elsabee, M.Z. (2011): Shelf life and delivery enhancement of vitamin $\mathrm{C}$ using 
chitosan nanoparticles. Food Chemistry, 126(3), 935-940.

Allain, C.C.; Poon, L.S.; Chan, C.S.; Richmond, $W$. and Fu, P.C. (1974): Enzymatic determination of total serum cholesterol. clin. Chim Apr;20(4):470-5. PMID: 4818200.

Association of Official Analysis Chemists (AOAC) (2001):

Official methods of Analysis of AOAC International. 19th ed. Association of Analytical Communities International, Virginia, USA.

Bakalli, R.I.; Pesti, G.M.; Ragland,W.L. and Konjufca, V. (1995): Dietary Copper in Excess of Nutritional Requirement Reduces Plasma and Breast Muscle Cholesterol of Chickens. Poult. Sci. 74 (2): 360-365.

Chen, Q.-L.; Luo, Z. and Pan, Y.X. (2013): Differential induction of enzymes and genes involved in lipid metabolism in liver and visceral adipose tissue of juvenile yellow catfish Pelteobagrus fulvidracoexposed to copper. Aquatic Toxicology, vol. 136-137, pp.72-78.

Dawood, M.A.O.; Koshio, S.; Ishikawa, M. and Yokoyama, S. (2015): Interaction effects of dietary supplementation of heatkilled Lactobacillus plantarum and $\beta$ - glucan on growth performance, digestibility and immune response of juvenile red sea bream, Pagrus major. Fish \& Shellfish Immunology, 45: 3342.
Dube, A.; Nicolazzo, J.A. and Larson, I. (2010): Chitosan nanoparticles enhance the intestinal absorption of the green tea catechins (+) catechin and (-) -epigallocatechin gallate. Eur. J. Pharm. Sci., 41: 219-225

El Basuini, M.F.; El-Hais, A.M.; Dawood, M.A.O.; Abou-Zeid, A.E.; $\quad$ EL-Damrawy, S.Z.; Khalafalla, M.M.E. and Dossou, S. (2016): Effect of different levels of dietary copper nanoparticles and copper sulphate on growth performance, blood biochemical profiles, antioxidant status and immune response of red sea bream (Pagrus major). Aquaculture, 455: 32-40.

Faiz, H.; Zuberi, A.; Nazir, S.; Rauf, M. and Younus, N. (2015): Zinc Oxide, Zinc Sulfate and Zinc Oxide Nanoparticles as Source of Dietary Zinc: Comparative Effects on Growth and Hematological Indices of Juvenile Grass Carp (Ctenopharyngodon idella). International Journal of Agriculture and Biology, 17, 568-574.

Farah, H.S.; Al-Atoom, A.A. and Shehab, G.M. (2012): Explanation of the decrease in alkaline phosphatase (ALP) activity in hemolysed blood samples from the clinical point of view: In vitro study. Jordan Journal of Biological Sciences, 5(2): 125-128.

Gatlin, D.M.III. and Wilson, R.P. (1986): Dietary copper 
requirement of fingerling channel catfish. Aquaculture, 54, 277285.

Handy, R.D. (2012): Nanotechnology in Fisheries and Aquaculture. Fisheries Society of the British Isles School of Biomedical and Biological Sciences, University of Plymouth, Drake Circus, Plymouth. UK.

Khan, K.U.; Zuberi, A.; Nazir, S.; Fernandes, J.B.; Jamil, Z. and Sarwar, H. (2016): Effects of dietary selenium nanoparticles on physiological and biochemical aspects of juvenile Tor putitora. Turkish Journal of Zoology, 40(5), 704-712.

Kim, S.G. and Kang, J.C. (2004): Effect of dietary copper exposure on accumulation, growth and hematological parameters of the juvenile rockfish, Sebastes schlegeli. Mar. Environ. Res., 58: 65-82.

Lanno, R.P.; Slinger, S.J. and Hilton, J.W. (1985): Maximum tolerable and toxicity levels of dietary copper in rainbow trout (Salmo gairdneri

Richardson). Aquaculture, 49: 257-268.

Maret, W. (2000): The function of zinc metallothionein: a link between cellular zinc and redox site. J. Nutr. 130, 1455S-1458S.

Marsh, W.H.; finger, hut. B. and kirsch, E. (1959): Adaptation of an alkaline phosphatase method for automatic colorimetric analysis. Clinical Chemistry. 1959 Apr; 5(2): 119-126.

Mohamad, Fazilati. (2013): Investigation toxicity properties of zinc oxide nanoparticles on liver enzymes in male rat. European Journal of Experimental Biology V3(1), 97103.

Mohseni, M.; Pourkazemi, M. and Baim, S.C. (2014): Effects of dietary inorganic copper on growth performance and immune response of juvenile beluga, Huso huso. Aquaculture Nutrition, 20: 547-556.

Murray, R.K.; Granner, D.K.; Mayes, P.A. and Rodwell, V.W. (2003): Harper's Illustrated Biochemistry, 26th Edition, McGraw-Hill, Medical Publishing Division. 818 p.

Najafzadeh, H.; Ghoreishi, S.M.; Mohammadian, B.; Rahimi, E.; Afzalzadeh, M.R.;

Kazemivarnamkhasti, $M$. and Ganjealidarani, H. (2013): Serum biochemical and histopathological changes in liver and kidney in lambs after zinc oxide nanoparticles administration, Vet World 6(8): 534-537, doi: 10.5455

/vetworld.2013.534-537

NRC (National Research Council), (1993): Nutrient Requirements of Fish. National Acadey Press, Washington DC, USA

Onuegbu, U.C.; Agarwal, A. and Singh, N.B. (2018): Growth Performance of Cultured African Catfish (C.Gariepinus) Fingerlings in the Presence of Nano and MacroCuO Feed Supplements. Journal of Scientific \& Industrial Research, 77: 499-503 
Prasad, A.S. (2014): Zinc is an antioxidant and antiinflammatory agent: Its role in human health. Frontiers in Nutrition, 1 : 14. doi:10.3389/fnut.2014.00014

Rather, M.A.; Sharma, R.; Aklakur, M.; Ahmad, S.; Kumar, N.; Khan, M. and Ramya, V.L. (2011): Nanotechnology: a novel tool for aquaculture and fisheries development. A prospective mini-review. Fisheries and Aquaculture Journal, 16, 1-5.

Saddick, S.; Afifi, M. and Osama A. Abu Zinada (2017): Effect of Zinc nanoparticles on oxidative stress-related genes and antioxidant enzymes activity in the brain of Oreochromis niloticus and Tilapia zilli. Saudi Journal of Biological Sciences, 24: 1672-1678

Sedeño-Díaz, J.E. and López-López, E. (2012): Freshwater fish as sentinel organisms: From the molecular to the population level, a review. New Advances and Contributions to Fish Biology, Prof. Hakan Turker (Ed.), ISBN: 978-953-51-0909-9, InTech, $10.5772 / 54825$.

Shaw, B.J. and Handy, R.D. (2006): Dietary copper exposure and recovery in Nile tilapia, Oreochromis niloticus. Aquat. Toxicol., 2006 Feb 10;76(2):11121. doi: 10.1016/j.aquatox. 2005.10.002. Epub 2005 Nov 18. PMID: 16298437. 76: 111-121.
Shephard, M.D. and Mezzachi, R.D. (1986): Clin Biochem Revs, 4:61-7, 1983.

Siklar, Z.; Tuna, C.; Dallar, Y. and Tanyer, G. (2003): Zinc deficiency: a contributing factor of short stature in growth hormone deficient children. J. Trop. Pediatr., 49: 187-188

Swain, P.; Das, R.; Das, A.; Padhi, S.K.; Das, K.C. and Mishra, S.S. (2019): Effects of dietary zinc oxide and selenium nanoparticles on growth performance, immune responses and enzyme activity in rohu, Labeo rohita (Hamilton), Aquaculture Nutrition; 25:486494.

Swain, P.S.; Rao, S.B.N.; Rajendran, D.; Dominic, G. and Selvaraju, S. (2016): Nano zinc, an alternative to conventional zinc as animal feed supplement: A review. Animal Nutrition, 2(3): 134-141.

Taheri, S.; Banaee, M.; Haghi, B.N. and Mohiseni, M. (2017): Effects of dietary supplementation of zinc oxide nanoparticles on some biochemical biomarkers in common carp (Cyprinus carpio), Int. J. Aquat. Biol. 5(5): 286-294. Tan, X.Y.; Luo, Z.; Liu, X. and Xie, C. $X$. (2011): Dietary copper $(\mathrm{Cu})$ requirement for juvenile yellow catfish Pelteobagrus fulvidraco. Aquaculture Nutrition, 17: 170176. 
Tawfik, M.M.M.; Moustafa M.M.; Abumourad I.M.K.; El-Meliegy, E.M. and Refai, M.K. (2017): Evaluation of Nano Zinc Oxide feed additive on tilapia Growth and Immunity, 15th International Conference on Environmental Science and Technology Rhodes, Greece, 31 August to 2 September 2017
Tietz, N.W.(1986): Textbook of clinical chemistry. WB saunders, Philadelphia. pp 271- 1281.

Xiong, D.; Fang, T.; Yu, L.; Sima, X. and Wentao, Z. (2011): Effects of nanoscale $\mathrm{TiO} 2, \mathrm{ZnO}$ and their bulk counterparts on zebrafish: Acute toxicity, oxidative stress and oxidative damage. Science of the Total Environment, 409: 1444-1452. 


\section{تأثير استبال النحاس والزنتك الغير عضوى فى عليقة اسمائك القراميط بالنحاس والزتلك فى الصورة المتناهية الصغر على الاداء والقياسات الكيميائية}

مروة احمد فواز ، محد عبل الله موسى ، محمد عبل العزبيز /حمد ، سبي محمد حجازى

E-mail: marwaahmedfwaz@gmail.com Assiut University web-site: www.aun.edu.eg

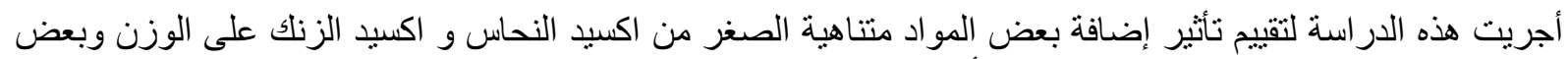

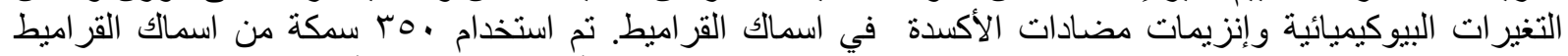

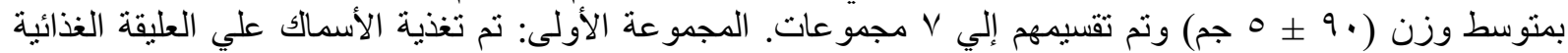

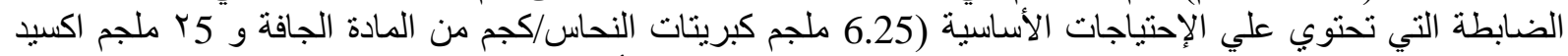

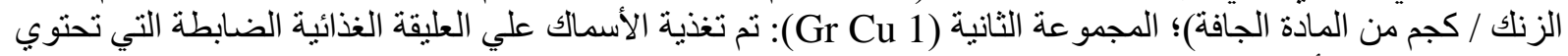

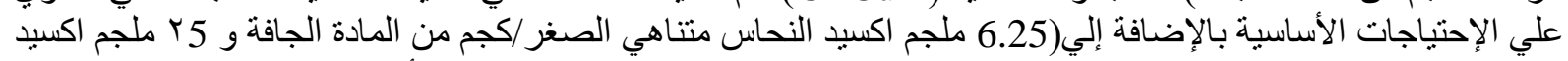

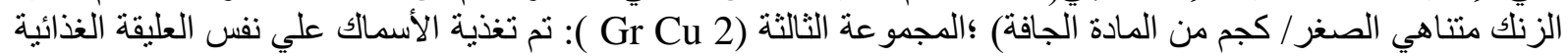

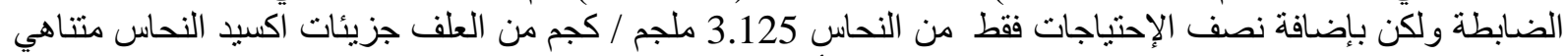

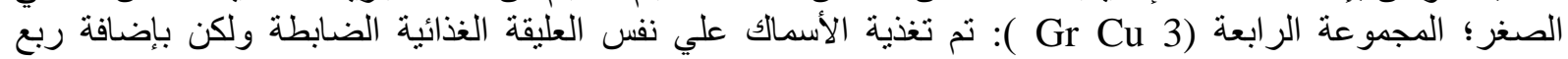

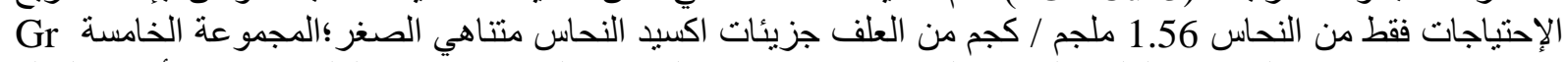

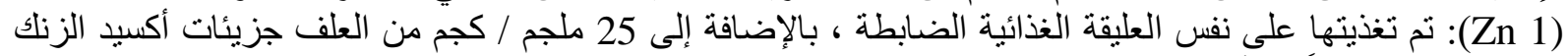

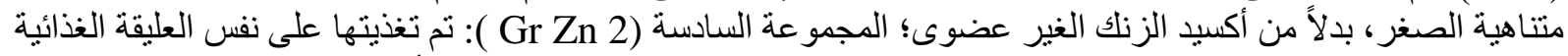

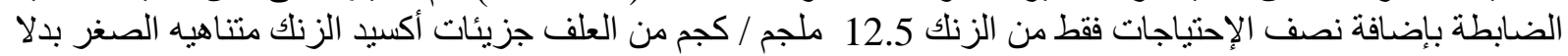

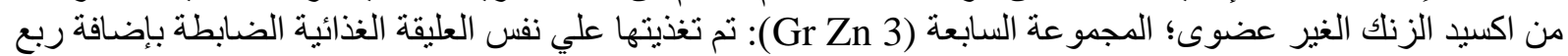

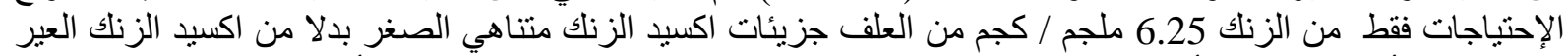

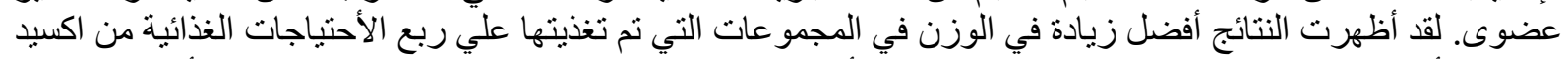

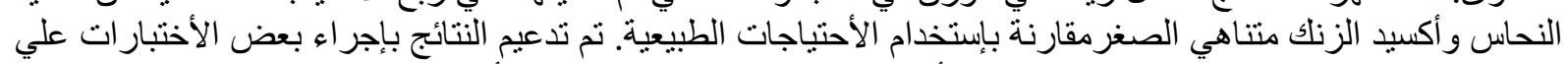

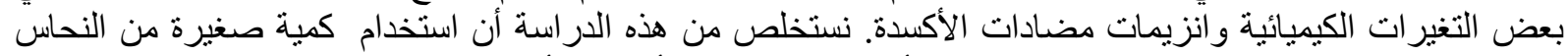

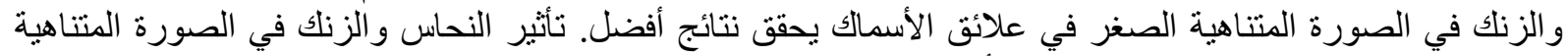

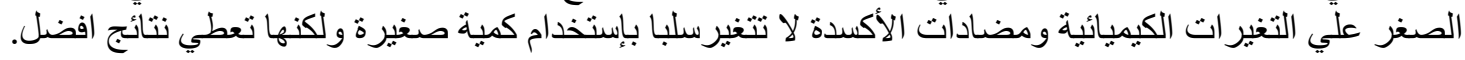

